\title{
Measuring SPILl-over EfFects of Foreign MARKets \\ ON THE JSE BEFORE, DURING AND AFTER INTERNATIONAL FINANCIAL CRISES
}

\author{
Andre Heymans and Ricardo da Camara \\ School of Economics, North-West University
}

Accepted: June 2013

\begin{abstract}
There is a large body of research that proves the co-movement of international stock markets over time. This co-movement manifests through various instruments ranging from stocks and bonds, to soft commodities and can be visualised as returns and volatility spill-over effects. During the most recent financial crisis, it was once again highlighted that no market is immune to spill-over effects from other international markets. By employing an aggregate-shock (AS) model, returns and volatility spill-over effects of the Hang Seng, London, Paris, Frankfurt and New York stock markets to the JSE are confirmed. The findings also confirm the JSE All share index is directly affected through contagion by the returns of the economic area where the crisis originates. However, the results further confirm that South Africa has progressed in shielding its stock market against financial crises in recent times. These findings hold important implications for stock portfolio managers in South Africa.
\end{abstract}

Key words: volatility spill-over effects, financial crises, financial market contagion

JEL: G1, 2, 11, 15

1

\section{Introduction}

Over the past three decades financial markets around the world have become increasingly interconnected (Baele \& Inghelbrecht, 2010). Although emerging economies too have benefitted from global financial integration, they have also succumbed to increased financial turbulence in the form of heightened asset price volatility. The South African financial market was no exception, and was severely affected by financial crises over the past 15 years. Investors in countries affected by these crises may lose confidence in capital markets when sharp asset price fluctuations cannot be explained by fundamental economic factors, leading to a reduction in capital flows towards equity markets (Daly, 2008:2378). It is therefore important to measure volatility in an attempt to better understand the fundamental economic factors that drive the world economy. It is however not sufficient to measure the volatility in the local market alone. In order to fully understand the dynamics of an equity market, it is necessary to be informed where this volatility originates. Only after acquiring this knowledge, can market participants hedge their positions accordingly.

To date, the current literature does not address the returns and volatility spill-over effects from foreign markets to the JSE, highlighting the progression of these effects over different crisis periods. Although Collins and Biekpe (2003) investigated the possibility of contagion from the 1997 Asian crisis on African economies, including South Africa, no attempt has yet been made to investigate at macro level the degree to which international financial crises influence the South African equity market, in terms of price and volatility transmission. The possibility of changes in the nature of price and volatility transmission before, during, and after a financial crisis has occurred, have also not yet been investigated.

This study thus aims to improve the understanding of how the South African equity market interacts with international equity markets by identifying the degree of price and 
volatility transmission before, during, and after an international financial crisis. This will be achieved by identifying the origins of the returns and volatility spill-over effects onto the South African stock exchange by means of an Aggregate Shock (AS) model. By employing the AS model, it is possible to discern what amount of returns and volatility movement on the JSE originates from foreign markets. The paper also aims to add to the current body of knowledge exposing the relationship between the JSE and foreign stock markets over the life span of the previous four major financial crises. This insight is not only of value for market participants, but also for policy makers. If investors and policy-makers know the level of price and volatility transmission between international and local equity markets in general, risk assessment and indeed price risk management, could be improved substantially. As such, the results seem to prove this hypothesis in that stringent financial regulation over time reduced South Africa's sensitivity to international crises.

The remainder of the paper is organised as follows. Section 2 briefly expands on literature of contagion. Section 3 provides a description of the data as well as the methods used to arrive at the results. Section 4 gives a discussion of the results after which a conclusion is presented in section 5 .

2

\section{Contagion}

There are a vast number of studies on the transmission of prices and volatility across exchanges. See for example Barclay, Litzenberger and Warner (1990), ${ }^{1}$ Hamao, Masulis and Ng $(1990)^{2}$ and Lin, Engle and Ito (1994). ${ }^{3}$ In addition to the above studies, Kanas (1998) studied the volatility spill-over amoung the three largest European equity markets and found that there were a greater number of spillover effects during the post-crash period of 1987, than during the pre-crash period, indicating greater interdependence after the market crash among the markets studied. ${ }^{4}$ Locally, Piesse and Hearn (2005) found evidence of volatility and returns transmission between Sub-Saharan African equity markets, while Collins and Abrahamson (2004) investigated whether various African equity markets are more integrated regionally or globally.

In order to measure the impact of different markets on each other, researchers often prefer data on the volatility of returns in financial markets over data on returns alone (Tanizaki \& Hamori, 2009:28). The reason being that return volatility provides useful data on information flow and information linkages between markets (Ross, 1989). Information linkages are of the utmost importance to financial market participants. Equity traders in a given market for example, incorporate not only domestic information, but also information generated by other equity markets into their buy and sell decisions. Provided that the information generated by international equity markets are relevant for the pricing of domestic securities, this behaviour by traders is also consistent with the efficient market hypothesis (EMH) (Koutmos \& Booth, 1995:1).

Although the economic literature on contagion has focused mainly on the analysis of how first moment changes in key variables are transmitted between countries (Edwards, 2000:10) the literature on the transmission of changes in second moments (volatility) between countries is growing (Tanizaki \& Hamori, 2009:29). Financial volatility influences a variety of economic decisions, such as investment strategies and the pricing of risk. It is thus important to establish whether changes in a volatility system are independent between countries, or if these changes are the result of the transmission of international financial crises (Edwards, 2000:10). The significance of financial crises is further emphasised by their effect on economic fluctuations. Disruptions to the efficient functioning of financial markets can result in the increased cost of financial intermediation; curbing the availability of an economic lifeline in the form of credit; restraining activity in the real sector of the economy and eventually exposing a country to periods of low growth and/or economic recession and leading to overall financial instability (Allen \& Gale, 2000:2).

Financial stability is thus greatly affected by volatility, and during an international financial 
crisis, financial stability is of paramount importance, not only in the particular crisis country, but also in countries that have trade relations with the crisis country concerned. Investors in the affected countries may lose confidence in capital markets when sharp asset price fluctuations cannot be explained by fundamental economic factors. This situation may result in a reduction of capital flows towards equity markets (Daly, 2008:2378). The effects of financial market volatility through crises are seen in the relationship between financial market uncertainty and public confidence (Romer, 1990).

Although it is important to measure volatility for purposes of establishing financial stability, there are various other reasons for measuring volatility. On firm level, the volatility of a firm's capital structure may provide important information on the probability of default for individual firms. The volatility of equity prices can affect equity market liquidity, since volatility is an important element in determining the bid-ask spread of an equity's price. Volatility also determines the cost of hedging techniques, reduces the level of investment participation by consumers, influences consumption patterns, leverage decisions, corporate capital investment decisions and macro-economic variables. Should high volatility persist, it may even hamper the allocation efficiency of capital due to regulatory requirements, forcing firms to allocate a bigger percentage of capital towards cash or equivalent investments as a risk management buffer against the unpredictability inherent in markets (Daly, 2008:2378).

While the measurement of volatility is clearly important, the measurement of volatility transmission also becomes important in cases where the economy involved has close links with other economies in which high volatility persists. Volatility transmission or spill-over effects normally occur via transmission channels that are divided into three categories, namely trade linkages, financial linkages and linkages based on investor behaviour (Boshoff, 2006:63). Although these linkages transmit spill-over effects in their own unique way, it is often very difficult to test for them separately (see for example Glick \& Rose, 1999;
Kaminsky \& Reinhart, 2000; Van Rijckeghem \& Weder, 2001).

Direct real linkages (trade linkages), such astrade in goods and services between different countries, are the easiest way for a shock in one country to be transmitted to others. Financial markets may be related if real linkages exist between countries. This is certainly the case when asset values are determined by common macro-economic factors. These trading partners may be negatively affected through losses in competitiveness (Forbes, 2004:60) and a decline in demand (income effect) from countries experiencing a financial crisis (van Rijckeghem \& Weder, 2001). Local demand for imported goods may also decline significantly during a domestic financial crisis, which in turn, may affect the export performance of trading partners to the crisis country (Boshoff, 2006:64).

The second category explaining the transmission of a crisis is the linkages created by financial markets (financial linkages). This transmission mechanism can be particularly effective when a financial institution's exposure in a crisis country is large, and losses require capital asset ratios as well as risk exposure to be readjusted (Sbracia \& Zaghini, 2003:728). There are mainly two channels through which financial institutions can transmit a financial crisis among the countries it operates in; lending activities and liquidity.

In terms of lending activities, banks are specifically exposed to financial linkages. Since cross-border integration between banks is a common feature of modern finance, a universal lender may end up being the main supplier of funds to numerous countries (Sbracia \& Zaghini, 2003:729). This situation may weaken the 'value at risk' position of this financial institution, and force capital withdrawals from its operation abroad in order to meet capital adequacy requirements (Sbracia \& Zaghini, 2003:729). The financial institution may also be required to meet margin calls, and possibly rebalance its portfolios in the specific crisis country (Van Rijckeghem \& Weder, 2001:294). This strategy of increasing risk exposure in the crisis country can lead to abrupt reductions of credit lines in non-crisis economies and put productive sectors in the 
non-crisis countries under economic pressure (Sbracia \& Zaghini, 2003:730).

The second channel, liquidity, is another important variable when dealing with contagion through financial linkages. Once a country moves into a market stress situation, liquidity usually dries up (Gatev \& Strahan, 2006:868). As experienced during the Sub-prime financial crisis, liquidity plays an important role in the functioning of international financial markets. International- and domestic interbank markets allow for efficient financial management by, for example, providing liquidity support to troubled institutions facing individual liquidity problems and reducing the opportunity costs of maintaining liquid reserves (Prati, Bartolini \& Bertola, 2003:2045).

The third category operates independently from the financial market system and is concerned with changes in investor expectations or sentiments (linkages based on investor behaviour). In some instances investor's portfolio decisions (as opposed to country characteristics), may help to explain contagion (Van Rijckeghem \& Weder, 2001:294). In response to economic shocks, some investors may be inclined to re-adjust their hedging strategies in order to protect themselves against changing macro-economic risks. However, it is not only portfolio managers that rebalance their portfolios after a wealth shock. Individuals too may find it necessary to rebalance their portfolios. As investors' risk perception change due to diminishing wealth, they may become more risk averse and move their portfolios toward less risky assets (Forbes, 2004:60). Leveraged investors may also be required to honour margin calls from clearinghouses, and thus be forced to liquidate their asset holdings (Boshoff, 2006:65; Forbes, 2004:61). When numerous investors follow this trend, a liquidity shock may be created, and due to information asymmetries, market participants may not be able to distinguish between a crisis country and non-crisis country (Boshoff, 2006:65). This creates a situation where asset prices in non-crisis countries face downward pressure form a sell-off in perceived risky assets, propagating the initial crisis across markets (Boshoff, 2006:65). As seen during the build-up of the dot-com bubble, the relationship between the real values of companies can be blurred by investors' feelings towards the equity of these companies. This "irrational exuberance" and similar "herding behaviour" among individual investors may once again be a source of contagion, as capital flows and financial markets are influenced by mass behaviour that aggravates boom periods as well as market busts (Kaminsky, Reinhart \& Vegh, 2003:4).

It is therefore clear that it is important for both market participants as well as policy makers to understand not only where returns and volatility spill-over effects originate, but also how they progress over time. Since market information evolves over the life span of a crisis, the impact of crises may be reduced if policy makers are able to develop policies efficiently. This can only be achieved if it is possible to predict this evolution in a manner of accuracy. This paper will therefore attempt to broaden the knowledge base on how these spill-over effects progress over crisis periods in the South African equity market.

\section{3}

\section{Data and Methodology}

Since the United States of America and the United Kingdom consistently remain by value within the top three rankings of South Africa's main trading partners, it follows logically that volatility in these markets should spill over to South Africa. Also, between 1997 and 2012, the European Union features very strongly within South Africa's top ten trading partner rankings, while the Asian region is mostly represented by Japan and China. From a financial linkage point of view, amongst others through direct participation in the equity and bond market foreigners are actively involved in South African financial markets. A large percentage of the top 40 companies listed on the Johannesburg Securities Exchange (JSE), are also listed and actively traded on international equity markets (examples include, Old Mutual, Anglo American Plc, BHP Billiton, Sasol and Investec).

However, the impact of international financial markets on the South African equity market does not always happen in real time. 
Since these markets do not trade under the same trading hours, and differences in opening and closing times exist between these interacting international financial markets, analysis may lead to spurious casual relationships (Cheung, Fung \& Tsai, 2010:88). In order to avoid the overlapping and nonsynchronous trading problem, weekly index returns are employed when testing for spillover effects from these markets to the JSE (see for example Cheung et al., 2010:88 and Hung \& Cheung, 1995:282). Since data of a higher frequency (e.g., intraday or daily) contains too much noise, while lower frequency data (e.g., monthly) makes it more difficult to capture changes in information, the use of weekly data is further justified. The data to be used for testing spill-over effects thus consist of weekly returns of the JSE All Share Index (proxy for South Africa), the CAC and the DAX (proxies for the Euro-zone), the Dow Jones Industrial Average Index (proxy for the USA), the
London Financial Times-Stock Exchange 100 Share index (proxy for the UK area) and the Hang Seng Index (proxy for the Asian region). The period under revision varies according to the financial crisis being studied. The reason for the varying length stems from the difference in length of each crisis. ${ }^{5}$ In order to capture the true spill-over effects of every crisis, it is necessary to ensure that only the data that stretches over the true time-frame of each crisis is captured.

In order to form a better idea of the comovement among world markets, figures 1 through 6 depict the daily percentage change in the index returns of the six markets under observation. It is interesting to note that the degree of volatility within each market varies according its region of origin. For example the daily volatility in returns around the period of the Asian financial crisis is higher on the Hang Seng than on the London FTSE100.

Figure 1

The daily JSE index returns and daily percentage change

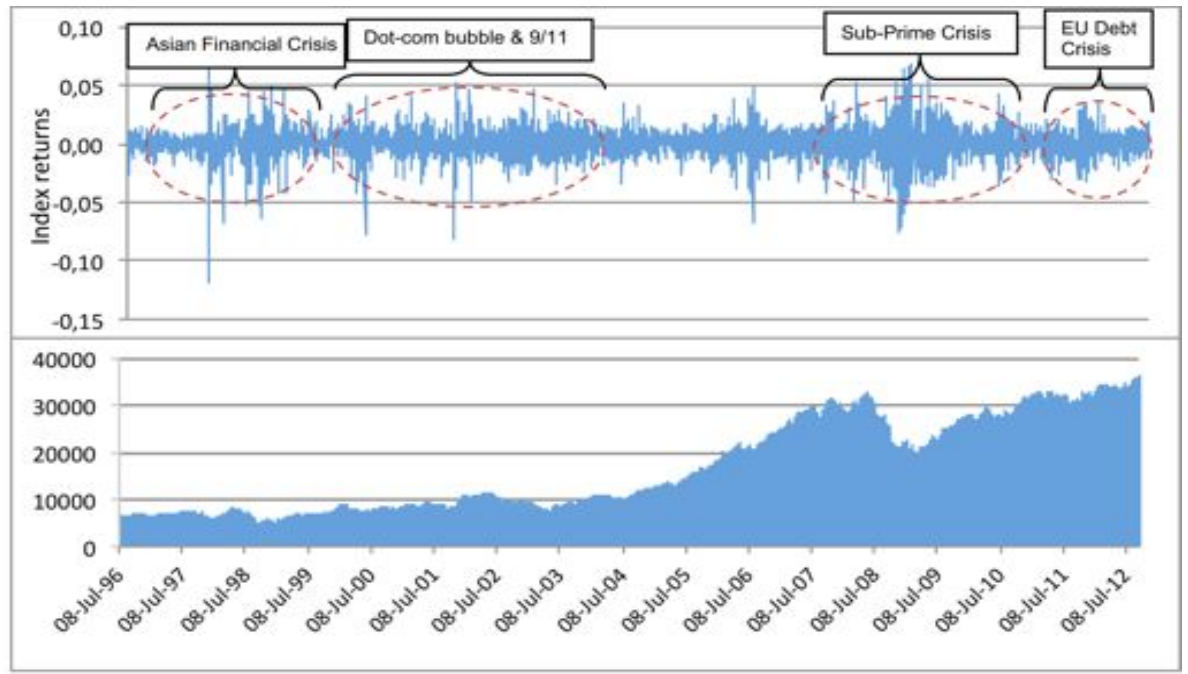

Source: McGregor BFA (2013) 
Figure 2

The daily CAC index returns and daily percentage change

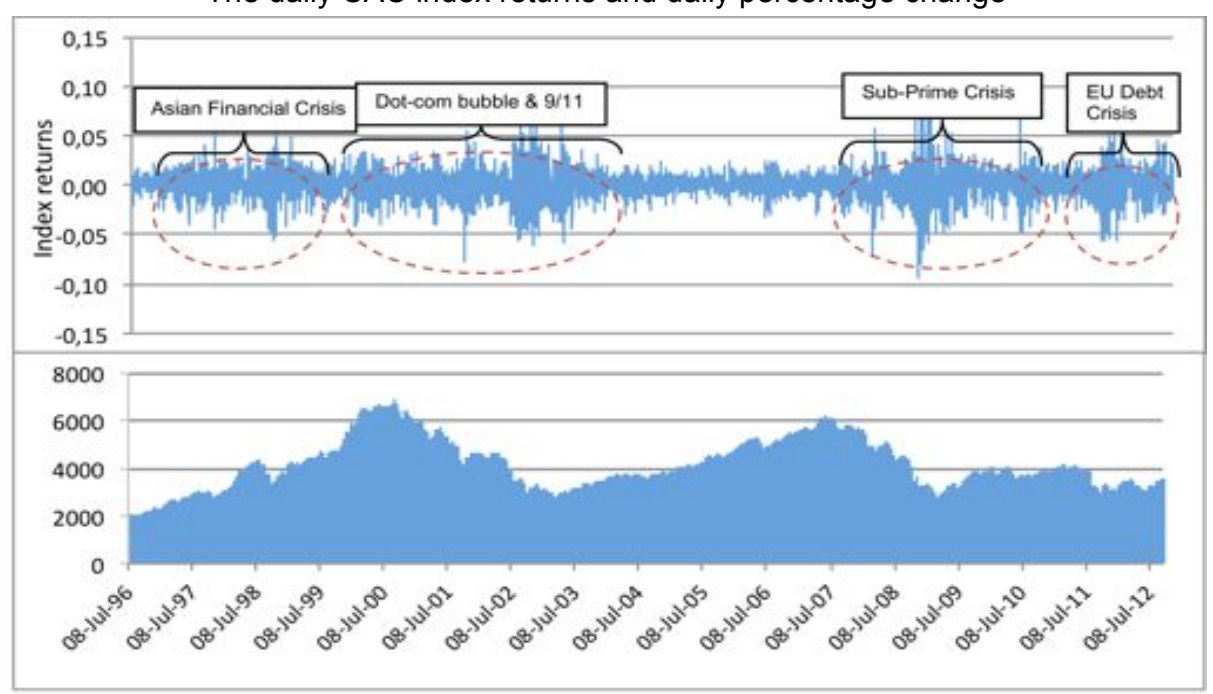

Source: McGregor BFA (2013)

Figure 3

The daily DAX index returns and daily percentage change

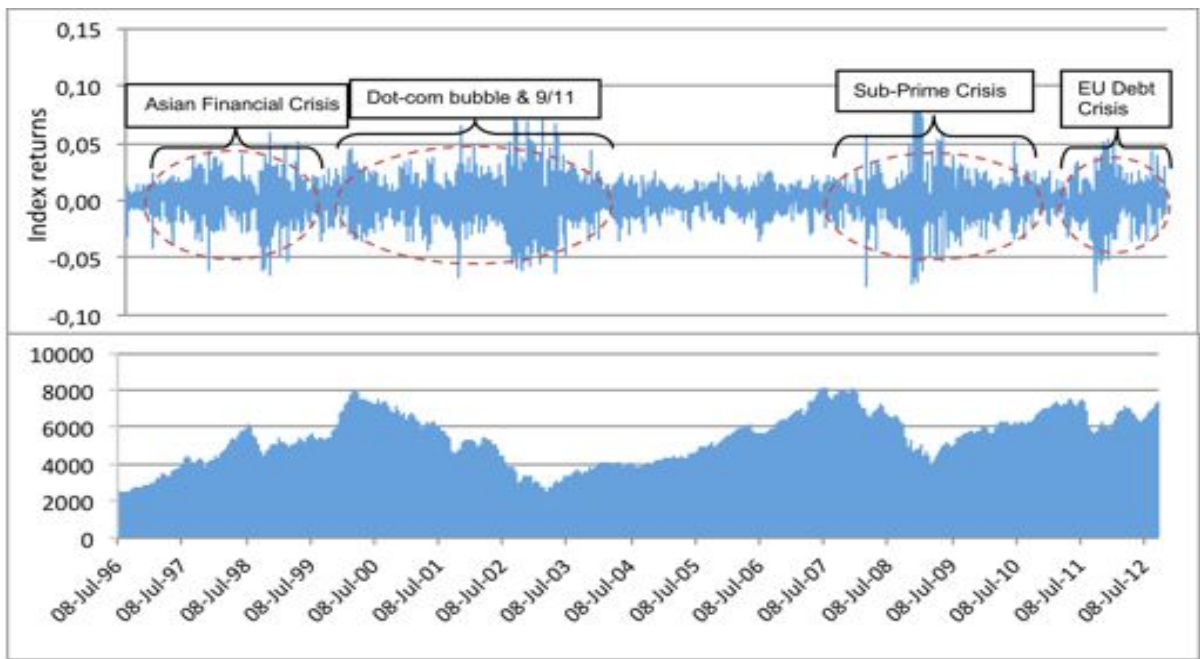

Source: McGregor BFA (2013) 


\section{Figure 4}

The daily DJIA index returns and daily percentage change

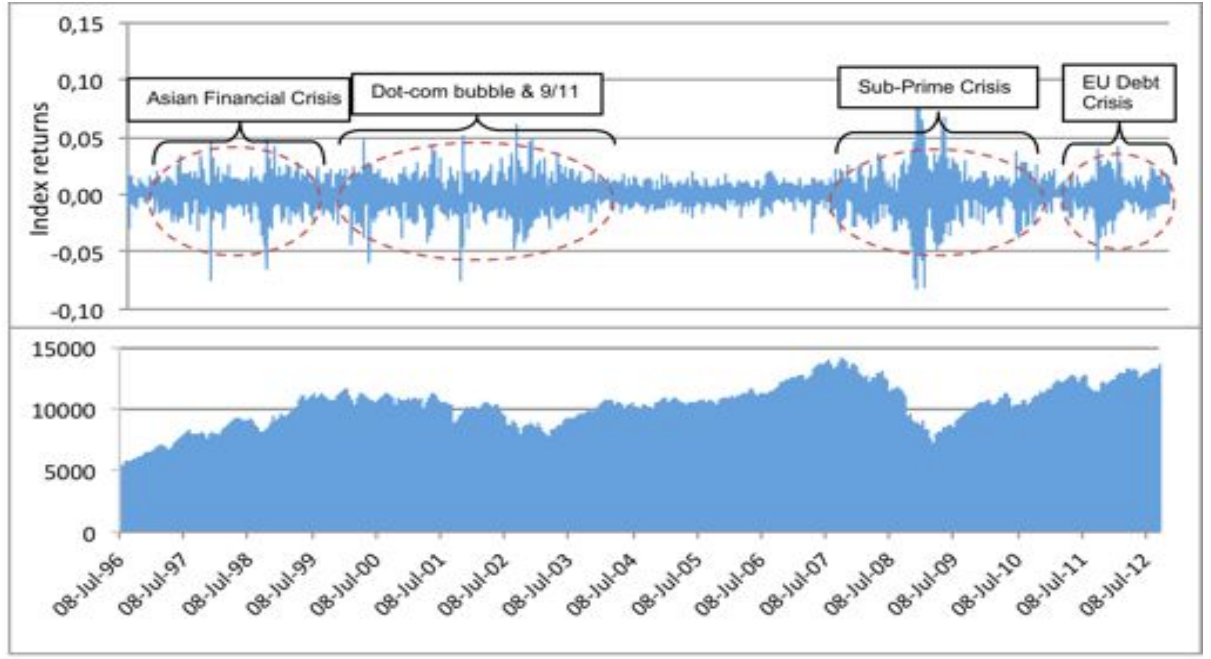

Source: McGregor BFA (2013)

Figure 5

The daily FTSE100 index returns and daily percentage change

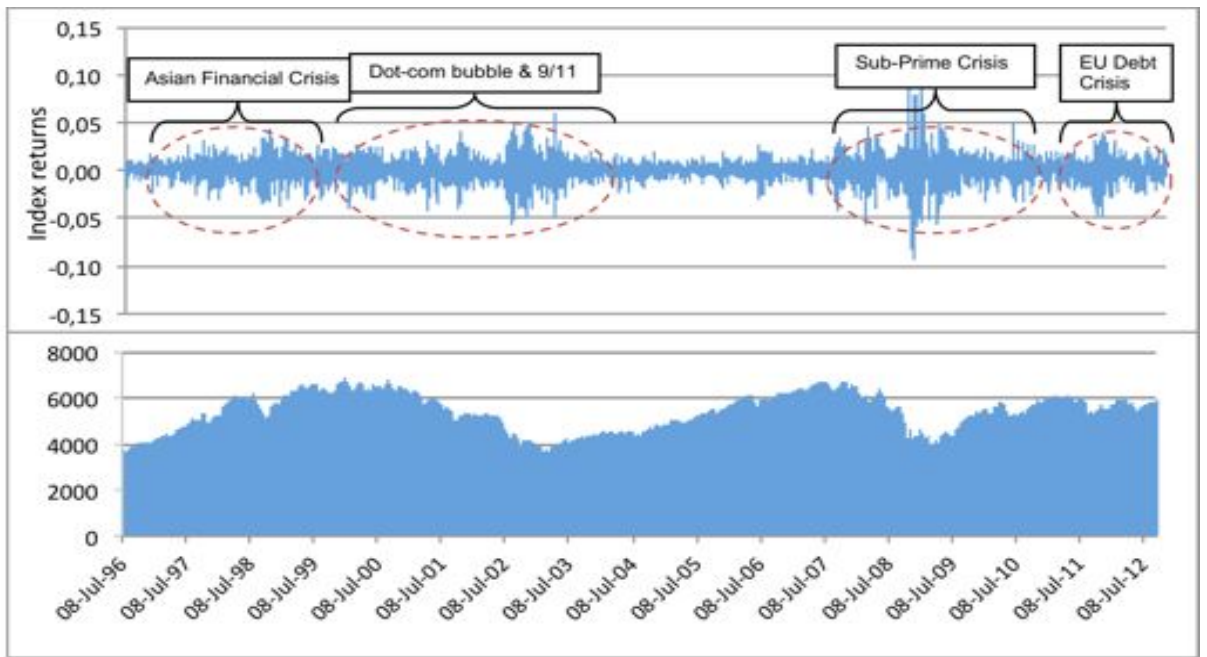

Source: McGregor BFA (2013) 


\section{Figure 6}

The daily Hang Seng index returns and daily percentage change

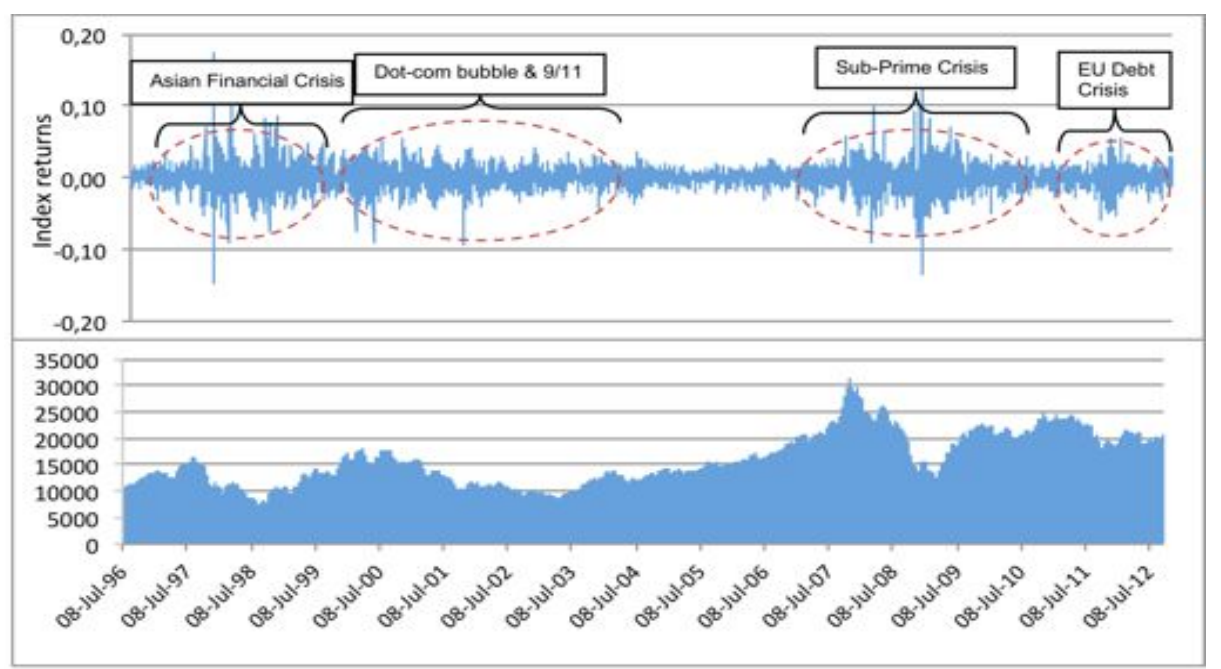

Source: McGregor BFA (2013)

In order to acquire a greater understanding of how the relationship, in terms of market efficiency, between the South African equity market and global equity markets evolved over the four crises under observation, the price and volatility transmission were tested by means of an Aggregate Shock (AS) model before, during and after each crisis period. ${ }^{6}$

The AS model follows a two-step procedure in which the fitted values of $e_{t}$ and $\sigma_{t}^{2}$ in equations 3.1 and 3.3 respectively, are obtained. These fitted values are then substituted in equations 3.2 and 3.4 respectively, before presenting and interpreting the estimated equations. In the AS model, the foreign weekly returns on a foreign market are specified as: ${ }^{7}$

$$
F W R_{t}=\alpha_{1}+\beta_{1} F W R_{t-1}+e_{t},
$$

where FWR is the foreign weekly return for period $\mathrm{t}$ and $e_{t}$ captures the factors that affect returns which are unexplained by the autocorrelation of the current weekly returns with the previous weekly returns (persistence). Thus assuming markets are efficient, $e_{t}$ represents that part of the returns which cannot be anticipated based on available public information when equity trading is initiated at the start of each week. Domestic weekly returns on the JSE at the same period $\mathrm{t}$ can be modelled as:

$$
J W R_{t}=\alpha_{2}+\beta_{2} J W R_{t-1}+\phi e_{t}+\mu_{t} .
$$

Equation 3.2 includes a coefficient $\phi$ which is the relationship between the foreign returns and the returns on the JSE. The error term, $e_{t}$ now represents the unexplained returns on the foreign equity market for period t. An Exponential Generalized Autoregressive Conditional Heteroskedasticity (EGARCH) process is used in order to determine the level of volatility spill-over between a foreign equity market and the JSE. It is assumed that the error term $e_{t}$ in equation 3.1 is normally distributed with a mean of zero and a variance that follows an $\operatorname{EGARCH}(\mathrm{p}, \mathrm{q})$ process:

$$
\ln \sigma_{f, t}^{2}=\varpi_{1}+\beta_{3} \ln \sigma_{f, t-1}^{2}+\gamma_{1} \frac{\varepsilon_{f, t-1}}{\sigma_{f, t-1}}+\alpha_{1} \frac{\left|\varepsilon_{f, t-1}\right|}{\sigma_{f, t-1}},
$$

where the natural $\log$ of the conditional variance for $e_{t}$ in period $\mathrm{t}$ is a function of the time invariable mean reversion value, $\varpi$, the natural $\log$ of the past conditional variance, $\sigma_{f, t-1}^{2}$, as well as the level of the standardised residuals, $\frac{\varepsilon_{f, t-1}}{\sigma_{f, t-1}}$, and absolute value of the standardised residuals, $\frac{\left|\varepsilon_{f, t-1}\right|}{\sigma_{f, t-1}}$. The subscript $f$ denotes foreign (that is CAC, DAX, DJIA, FTSE100 and Hang Seng). Finally, it is assumed that the error term of the JSE weekly returns 
$\mu_{t}$, is also normally distributed with a mean of

(p, q) process: zero and a variance that follows an EGARCH

$$
\ln \sigma_{j, t}^{2}=\varpi_{2}+\beta_{4} \ln \sigma_{j, t-1}^{2}+\gamma_{2} \frac{\varepsilon_{j, t-1}}{\sigma_{j, t-1}}+\alpha_{2} \frac{\left|\varepsilon_{j, t-1}\right|}{\sigma_{j, t-1}}+\kappa_{i} \sigma_{f, t}^{2} .
$$

In addition to the variables included in the variance specification of the foreign return equation, 3.1, the model specification of the variance of the JSE in equation 3.4 includes a foreign measure, $\sigma_{f, t}^{2}$ which allows for the testing of the relation between local volatility and foreign volatility. The $\kappa_{i} \sigma_{f, t}^{2}$ term in equation 3.4 is the foreign conditional variance term, and denotes the relation between local and foreign volatility. The inclusion of the terms $\frac{\varepsilon_{j, t-1}}{\sigma_{j, t-1}}$ and $\frac{\left|\varepsilon_{j, t-1}\right|}{\sigma_{j, t-1}}$ makes it possible to model the asymmetric volatility to past shocks as long as $\gamma_{2} \neq 0$. The $\gamma_{2}$ parameter in the EGARCH model measures the asymmetry or the leverage effect of volatility. If $\gamma_{2}<0$ then negative shocks (bad news/negative past errors) will have a greater effect on volatility than positive shocks (good news/positive past errors). When $\gamma_{2}>0$, then positive shocks (good news) have a greater impact on volatility than negative shocks (bad news). If $\gamma_{2}=0$ then the model is symmetric. Finally, $\beta_{4}$ is the autoregressive term on lagged conditional volatility, and thus reflects the weight given to the previous period's conditional volatility in the conditional volatility at period $t$. This parameter therefore allows for the measurement of volatility persistence. Different lag specification models were estimated for each data set and the appropriate lag specification for the EGARCH $(p, q)$ term was chosen where the Schwarz criterion (SC) values were minimised.

\section{4 \\ Results}

The AS model presented above allows one to formally test the relationship of both returns (price) and volatility on the JSE and a foreign equity market. The tables below report on the returns and volatility spill-over effects of each foreign market on the JSE before, during and after each crisis period. However, since it is challenging to draw meaningful comparisons with the clutter of all the variables, only the following variables are included in the tables below: returns spill-over coefficients, the volatility leverage effects $(\gamma)$, the volatility persistence coefficients $(\beta)$ and the volatility spill-over coefficients $(\kappa)$.

Table 1 therefore reports on the returns spill-over characteristics of the five foreign markets during the pre-crisis, crisis and postcrisis periods of the four crises under observation. Tables 2 through 4 report on the volatility characteristics regarding the interaction between the different foreign markets and the JSE.

From the mean equation results in Table 1 below, it is evident that the effect of weekly international returns on the JSE is positive and statistically significant during all the periods (pre-crisis, crisis and post-crisis periods) of all four crises besides for the impact of the returns transmission of the DJIA during the pre-crisis period of the Sub-prime crisis. This positive association indicates that positive returns on the foreign exchanges are linked to positive returns on the JSE and vice versa. It is further noteworthy that the relationship between these markets and the JSE strengthens over time for the pre-crisis period. In terms of the CAC's returns for example, a 1 per cent increase in the weekly CAC index's returns was followed by a 0.131 per cent increase in the weekly JSE All share index returns before the Asian financial crisis while a 1 per cent increase in the weekly CAC index's returns resulted in a 0.806 per cent increase in the weekly JSE All share index returns before the EU debt crisis. The same is also true for the DAX $(0.335$ per cent pre-Asian crisis to 0.715 per cent pre-EU debt crisis), the DJIA (0.224 per cent preAsian crisis to 0.916 per cent pre-EU debt crisis), the FTSE (0.297 per cent pre-Asian crisis to 0.846 per cent pre-EU debt crisis), and the Hang Seng (0.197 per cent pre-Asian crisis to 0.457 per cent pre-EU debt crisis). This situation is reversed during the crisis and post- 
crisis periods where the returns spill-over effect dissipates from the Asian financial crisis to the EU Debt crisis for the CAC, the DAX and the DJIA. By the post-crisis periods, the
FTSE100 and the Hang Seng only displayed slight increases from the Asian financial crisis to the EU Debt crisis.

\section{Table 1}

Returns spill-over effects - all four crises for pre-crisis, crisis and post-crisis periods

\begin{tabular}{|c|c|c|c|c|c|}
\hline \multicolumn{2}{|c|}{ Mean Equation } & Variable & Pre-Crisis & Crisis & Post-Crisis \\
\hline \multirow{4}{*}{ CAC } & $\rightarrow$ AFC & Cac_Resid & $0.130596 \dagger$ & $0.528666 \dagger$ & $0.377924 \dagger$ \\
\hline & $\rightarrow$ Dot-com & Cac_Resid & $0.620278 \dagger$ & $0.507278 \dagger$ & $0.745598+$ \\
\hline & $\rightarrow$ Sub-prime & Cac_Resid & $0.748618 \dagger$ & $0.731754 \dagger$ & $0.828298 \dagger$ \\
\hline & $\rightarrow$ EU debt & Cac_Resid & $0.806196 \dagger$ & $0.481091 \dagger$ & $0.352222 \dagger$ \\
\hline \multirow{4}{*}{ DAX } & $\rightarrow \mathrm{AFC}$ & Dax_Resid & $0.334661 \dagger$ & $0.718552 \dagger$ & $0.390237 \dagger$ \\
\hline & $\rightarrow$ Dot-com & Dax_Resid & $0.397403 \dagger$ & $0.406177 \dagger$ & $0.551017 \dagger$ \\
\hline & $\rightarrow$ Sub-prime & Dax_Resid & $0.720484 \dagger$ & $0.708518 \dagger$ & $0.717715 \dagger$ \\
\hline & $\rightarrow$ EU debt & Dax_Resid & $0.714684 \dagger$ & $0.367851 \dagger$ & $0.344167 \dagger$ \\
\hline \multirow{4}{*}{ DJIA } & $\rightarrow \mathrm{AFC}$ & DJIA_Resid & $0.224165 \dagger$ & $1.039702 \dagger$ & $0.683078 \dagger$ \\
\hline & $\rightarrow$ Dot-com & DJIA_Resid & $0.365943 \dagger$ & $0.704479 \dagger$ & $1.030310 \dagger$ \\
\hline & $\rightarrow$ Sub-prime & DJIA_Resid & -0.176543 & $0.803556 \dagger$ & $0.947223+$ \\
\hline & $\rightarrow$ EU debt & DJIA_Resid & $0.916157 \dagger$ & $0.720688 \dagger$ & $0.660660 \dagger$ \\
\hline \multirow{4}{*}{ FTSE100 } & $\rightarrow \mathrm{AFC}$ & FTSE_Resid & $0.297245 \dagger$ & $0.550258 \dagger$ & $0.583942 \dagger$ \\
\hline & $\rightarrow$ Dot-com & FTSE_Resid & $0.721687 \dagger$ & $0.752176 \dagger$ & $1.371843 \dagger$ \\
\hline & $\rightarrow$ Sub-prime & FTSE_Resid & $1.088274 \dagger$ & $0.772072 \dagger$ & $0.795573+$ \\
\hline & $\rightarrow$ EU debt & FTSE_Resid & $0.846223 \dagger$ & $0.727625 \dagger$ & $0.590499 \dagger$ \\
\hline \multirow{4}{*}{ Hang Seng } & $\rightarrow \mathrm{AFC}$ & HS_Resid & $0.197338 \dagger$ & $0.224199 \dagger$ & $0.406156 \dagger$ \\
\hline & $\rightarrow$ Dot-com & HS_Resid & $0.227922 \dagger$ & $0.558409 \dagger$ & $0.782386 \dagger$ \\
\hline & $\rightarrow$ Sub-prime & HS_Resid & $0.487268 \dagger$ & $0.534373 \dagger$ & $0.449111 \dagger$ \\
\hline & $\rightarrow$ EU debt & HS_Resid & $0.457343 \dagger$ & $0.453196 \dagger$ & $0.408304 \dagger$ \\
\hline
\end{tabular}

† Signifies that the particular coefficient is statistically significant at the five per cent level and * at a ten per cent level. Asian financial crisis (AFC), Dot-com bubble (Dot-com), Sub-prime crisis (Sub-prime), European debt crisis (EU Debt)

These results suggests that the JSE moves more with world markets in 'normal' market conditions (pre-crisis periods) as time goes by (from the Asian financial crisis to the EU Debt crisis), but that market participants on the JSE 'ignore' international news quicker (crisis and post-crisis periods) as time goes by. This is interesting, as it seems that market participants on the JSE incorporated more 'bad news' during the Asian financial crisis, but paid less attention to 'bad news' by the EU Debt crisis. There could be many reasons for this behaviour. It could be that market participants had no real other options because their normal investment choices were exhausted (developed countries still pose a great amount of investment risk) - although, this seems unlikely. Another, more likely explanation could be that the South African financial system has become more resilient to spill-over effects from foreign countries over time. According to the IMF (2010:1), South Africa's sound regulatory system played an important role in limiting the effects of the Sub-Prime crisis on the local financial system. Factors that contributed to shielding the financial system from instability were; a well-capitalised financial sector and limited exposure of domestic financial institutions to risky foreign assets such as Sub-prime asset backed securities and credit default swaps (IMF, 2010:5).

When exploring the progression of returns spill-over effects over the life time of each crisis, similar trends are visible. Although the relationship between the foreign markets and the JSE grows stronger as each crisis progress, this trend seems to dissipate over time. Where all of the markets display higher return spillover effects during the Asian financial crisis and the Dot-com crisis, none of the markets 
displayed continued growth in integration over the full life cycle of the crisis, by the EU Debt crisis. This result is somewhat counter intuitive, since it is to be expected that external shocks would influence the local market more when global macroeconomic conditions are volatile. However, since this trend dissipates over time (from the Asian financial crisis to the EU Debt crisis) this emphasizes the fact that returns on the JSE are being influenced more over time during 'normal' market conditions but that these returns move more independently during and after crisis periods as time goes by.

Table 2

Volatility leverage effects - all four crises for pre-crisis, crisis and post-crisis periods

\begin{tabular}{|c|c|c|c|c|}
\hline \multicolumn{2}{|c|}{ Volatility leverage effects } & Pre-Crisis & Crisis & Post-Crisis \\
\hline \multirow{4}{*}{ CAC } & $\rightarrow$ AFC & -0.20227 & $-0.92131 \dagger$ & -0.33142 \\
\hline & $\rightarrow$ Dot-com & 0.12966 & -0.09247 & $-0.77984 \dagger$ \\
\hline & $\rightarrow$ Sub-prime & $-0.94081 \dagger$ & $0.32794 \dagger$ & 0.11527 \\
\hline & $\rightarrow \mathrm{EU}$ debt & 0.01586 & -0.04252 & -0.59348 \\
\hline \multirow{4}{*}{ DAX } & $\rightarrow \mathrm{AFC}$ & -0.22453 & -0.01815 & -0.12828 \\
\hline & $\rightarrow$ Dot-com & 0.03390 & $0.14582^{*}$ & $-0.75584 \dagger$ \\
\hline & $\rightarrow$ Sub-prime & $-1.01075 \dagger$ & -0.04107 & 0.24051 \\
\hline & $\rightarrow$ EU debt & 0.20574 & -0.04078 & -0.13991 \\
\hline \multirow{4}{*}{ DJIA } & $\rightarrow \mathrm{AFC}$ & -0.05743 & $0.45776^{*}$ & -0.42508 \\
\hline & $\rightarrow$ Dot-com & -0.16365 & -0.06114 & $-0.38684^{*}$ \\
\hline & $\rightarrow$ Sub-prime & -0.45760 & $0.30746^{*}$ & $0.49268 \dagger$ \\
\hline & $\rightarrow$ EU debt & 0.36427 & $-0.15573 \dagger$ & 0.02151 \\
\hline \multirow{4}{*}{ FTSE100 } & $\rightarrow \mathrm{AFC}$ & 0.25220 & -0.32293 & 0.11807 \\
\hline & $\rightarrow$ Dot-com & 0.18866 & -0.08621 & $-0.72071 \dagger$ \\
\hline & $\rightarrow$ Sub-prime & $-0.57015 \dagger$ & -0.07345 & -0.01431 \\
\hline & $\rightarrow \mathrm{EU}$ debt & -0.00817 & $-0.38039 \dagger$ & $-0.59759 \dagger$ \\
\hline \multirow{4}{*}{ Hang-Seng } & $\rightarrow \mathrm{AFC}$ & -0.11695 & -0.21419 & 0.02424 \\
\hline & $\rightarrow$ Dot-com & -0.03287 & 0.00409 & -0.31844 \\
\hline & $\rightarrow$ Sub-prime & $-0.31362 \dagger$ & 0.16632 & -0.13911 \\
\hline & $\rightarrow$ EU debt & -0.07124 & $0.15229 \dagger$ & 0.27592 \\
\hline
\end{tabular}

† Signifies that the particular coefficient is statistically significant at the five per cent level and * at a ten per cent level. Asian financial crisis (AFC), Dot-com bubble (Dot-com), Sub-prime crisis (Sub-prime), European debt crisis (EU Debt)

By making use of the EGARCH model it was also possible to measure the volatility characteristics of the JSE in terms of the influence that foreign markets exhibit onto the local bourse. Only four statistically significant volatility leverage effects were measured during the pre-crisis period. All four of these statistically significant volatility leverage effects were reported for the period before the Sub-prime crisis for all the markets besides the DJIA. Before the Sub-prime crisis the volatility on all the indices had a negative asymmetric impact on the JSE All share index, suggesting that negative returns on all the indices have a greater effect on the degree of current JSE All share index volatility.

Unlike the pre-crisis volatility conditions where all the volatility leverage effects had a negative asymmetric impact on the JSE, there are instances where positive asymmetric effects are reported for the crisis periods. The CAC for example, displays a negative volatility leverage effect during the Asian financial crisis but a positive volatility leverage effect during the Sub-prime crisis. The DAX displays a positive volatility leverage effect during the Dot-com crisis and the DJIA displays positive volatility leverage effects during the Asian financial crisis and Sub-prime crisis but negative volatility leverage effects during the EU Debt crisis. The other two markets only displayed volatility leverage effects during the EU Debt crisis negative volatility leverage effects displayed 
by the FTSE100 and positive volatility leverage effects displayed by the Hang Seng. These results suggest that market participants seem to react to a greater extent to positive news, and less so to negative news during crisis conditions. This situation is once again reversed during the post-crisis period in that most of the statistically significant leverage effects are negative. These effects are also more pronounced during the period after the Dot-com crisis.

Table 3

Volatility persistence effects - all four crises for pre-crisis, crisis and post-crisis periods

\begin{tabular}{|c|c|c|c|c|}
\hline \multicolumn{2}{|c|}{ Volatility persistence effects } & \multirow{2}{*}{$\begin{array}{l}\text { Pre-Crisis } \\
0.86012 \dagger\end{array}$} & \multirow{2}{*}{$\begin{array}{l}\text { Crisis } \\
0.49920 \dagger\end{array}$} & \multirow{2}{*}{$\begin{array}{r}\text { Post-Crisis } \\
0.56157 \dagger\end{array}$} \\
\hline \multirow{4}{*}{ CAC } & $\rightarrow \mathrm{AFC}$ & & & \\
\hline & $\rightarrow$ Dot-com & 0.26214 & 0.58169 & $0.88137 \dagger$ \\
\hline & $\rightarrow$ Sub-prime & $0.76967 \dagger$ & $0.72684 \dagger$ & $0.28201 \dagger$ \\
\hline & $\rightarrow$ EU debt & $0.34675^{*}$ & $-0.89172 \dagger$ & $-0.74899^{*}$ \\
\hline \multirow{4}{*}{ DAX } & $\rightarrow \mathrm{AFC}$ & 0.17791 & 0.24596 & $0.48866 \dagger$ \\
\hline & $\rightarrow$ Dot-com & $-1.05426 \dagger$ & $-0.65473 \dagger$ & $0.90999 \dagger$ \\
\hline & $\rightarrow$ Sub-prime & $0.86728 \dagger$ & $0.66629 \dagger$ & $0.46245 \dagger$ \\
\hline & $\rightarrow$ EU debt & $0.46044^{*}$ & $0.94738 \dagger$ & $0.23134 \dagger$ \\
\hline \multirow{4}{*}{ DJIA } & $\rightarrow \mathrm{AFC}$ & $0.70483 \dagger$ & 0.61302 & $0.38874 \dagger$ \\
\hline & $\rightarrow$ Dot-com & $0.63972 \dagger$ & $-0.69200 \dagger$ & $0.91085 \dagger$ \\
\hline & $\rightarrow$ Sub-prime & $-0.40996 \dagger$ & -0.19084 & 0.01183 \\
\hline & $\rightarrow$ EU debt & 0.00361 & $-0.80729 \dagger$ & $0.71738 \dagger$ \\
\hline \multirow{4}{*}{ FTSE100 } & $\rightarrow \mathrm{AFC}$ & $0.33858 \dagger$ & $-0.42613 \dagger$ & $0.65895 \dagger$ \\
\hline & $\rightarrow$ Dot-com & $0.65739 \dagger$ & $0.62714 \dagger$ & $0.66755 \dagger$ \\
\hline & $\rightarrow$ Sub-prime & $0.85548 \dagger$ & -0.32133 & $0.97112 \dagger$ \\
\hline & $\rightarrow$ EU debt & $0.98573 \dagger$ & $0.63217 \dagger$ & $0.13964 \dagger$ \\
\hline \multirow{4}{*}{ Hang-Seng } & $\rightarrow \mathrm{AFC}$ & $0.73102 \dagger$ & $-0.96883 \dagger$ & $0.60292 \dagger$ \\
\hline & $\rightarrow$ Dot-com & $-0.77490 \dagger$ & $-0.86613 \dagger$ & $0.41641 \dagger$ \\
\hline & $\rightarrow$ Sub-prime & $0.63538 \dagger$ & $-0.84264 \dagger$ & $-0.83509 \dagger$ \\
\hline & $\rightarrow$ EU debt & $-0.92760 \dagger$ & $0.64832 \dagger$ & 0.29113 \\
\hline
\end{tabular}

† Signifies that the particular coefficient is statistically significant at the five per cent level and * at a ten per cent level. Asian financial crisis (AFC), Dot-com bubble (Dot-com), Sub-prime crisis (Sub-prime), European debt crisis (EU Debt)

All of the volatility persistence coefficients are significant during the period before the Asian financial crisis, with the exception over this period of the DAX. Volatility persistence was also present for all markets besides the CAC in the period before the Dot-com crisis. The period before the Sub-prime crisis is characterised by the presence of volatility persistence for all the indices, while the period before the EU Debt crisis is defined by the presence of volatility persistence for all the markets besides the DJIA.

All the coefficients were also smaller than one, which according to Xu and Fung (2005) is a requirement for the volatility persistence terms to be stable. A high level of volatility persistence implies that fluctuations will remain in the markets for an extended period.
This situation will lead to greater uncertainty from market participants. A heightened level of uncertainty has important consequences for risk management, since investor decisions based on expectations result in higher volatility of equity returns.

As was the case with the pre-crisis periods, the volatility persistent coefficients are mostly statistically significant for all the crisis periods under review. Once again all the coefficients are stable (smaller than one), with volatility persistence increasing from the Asian financial crisis to the EU Debt crisis for the DAX, FTSE100 and the Hang Seng, and volatility persistence decreasing over the same period for the CAC and the DJIA. These results are consistent with the pre-crises results for all the markets except the Hang Seng. 
When investigating the progression of volatility persistence from pre-crisis period to post-crisis period, volatility persistence decrease from the pre-crisis period to the post-crisis period in nine instances, and increases from pre-crisis to post-crises eleven times. The results are mixed for the various crises. During the Asian financial crisis, volatility persistence increased from the DAX and FTSE100, and decreased from the CAC, DJIA and the Hang Seng over the lifespan of the crisis. During the Dot-com crisis, volatility persistence increased over all the markets for the lifespan of the crisis. For the lifespan of the Sub-prime crisis, volatility persistence decreased for the CAC, DAX and Hang Seng and increased for the DJIA and the FTSE100. The results are also mixed over the EU Debt crisis with decreasing volatility persistence originating from the CAC, DAX and FTSE100 and increasing volatility persistence originating from the DJIA and the Hang Seng.

It is interesting that volatility persistence increases over the lifespan of the Dot-com crisis, and that the DJIA itself exhibits the highest level of volatility persistence once the Dot-com crisis and 9/11 terror attacks had passed. Market participants thus seem to have become more uncertain with regards to their returns from foreign markets, which in turn resulted in heightened levels of volatility. The reason for this could have been driven by uncertainty over the possibility of further terrorist attacks, or uncertainty surrounding what the U.S. government would do about these attacks in the time after the crisis.

Table 4

Volatility spill-over effects - all four crises for pre-crisis, crisis and post-crisis periods

\begin{tabular}{|c|c|c|c|c|}
\hline \multicolumn{2}{|c|}{ Volatility spill-over effects } & Pre-Crisis & Crisis & Post-Crisis \\
\hline \multirow{4}{*}{ CAC } & $\rightarrow \mathrm{AFC}$ & -0.39167 & -0.32324 & 0.02392 \\
\hline & $\rightarrow$ Dot-com & -1.01693 & $0.07767 \dagger$ & -0.07613 \\
\hline & $\rightarrow$ Sub-prime & 0.01672 & $0.21144 \dagger$ & $-0.53607 \dagger$ \\
\hline & $\rightarrow$ EU debt & $-1.01655 \dagger$ & $0.58357^{*}$ & 0.64811 \\
\hline \multirow{4}{*}{ DAX } & $\rightarrow \mathrm{AFC}$ & $0.45507^{*}$ & $0.70176^{*}$ & -0.31142 \\
\hline & $\rightarrow$ Dot-com & 0.30301 & 0.43803 & $0.13903 \dagger$ \\
\hline & $\rightarrow$ Sub-prime & 0.20938 & -0.05967 & -0.20280 \\
\hline & $\rightarrow$ EU debt & -0.21448 & 0.10504 & 0.20118 \\
\hline \multirow{4}{*}{ DJIA } & $\rightarrow \mathrm{AFC}$ & -0.33871 & $0.91780^{*}$ & $0.34677^{*}$ \\
\hline & $\rightarrow$ Dot-com & $0.43017 \dagger$ & 0.43673 & -0.04028 \\
\hline & $\rightarrow$ Sub-prime & $0.87581 \dagger$ & $-0.14471 \dagger$ & -0.03610 \\
\hline & $\rightarrow$ EU debt & -0.00345 & 0.09598 & 0.26777 \\
\hline \multirow{4}{*}{ FTSE100 } & $\rightarrow \mathrm{AFC}$ & -0.25807 & $2.82449 \dagger$ & 0.17837 \\
\hline & $\rightarrow$ Dot-com & -0.09434 & 0.25208 & 0.16431 \\
\hline & $\rightarrow$ Sub-prime & -0.08284 & $-1.57562 \dagger$ & 0.40119 \\
\hline & $\rightarrow$ EU debt & -0.23303 & 0.16162 & $0.13126 \dagger$ \\
\hline \multirow{4}{*}{ Hang-Seng } & $\rightarrow \mathrm{AFC}$ & 0.02695 & -0.25372 & $0.34279 \dagger$ \\
\hline & $\rightarrow$ Dot-com & $-0.72608^{*}$ & 0.13955 & -0.20210 \\
\hline & $\rightarrow$ Sub-prime & -0.13448 & -0.02955 & -0.19290 \\
\hline & $\rightarrow$ EU debt & -0.23962 & $-0.54205 \dagger$ & -0.15822 \\
\hline
\end{tabular}

t Signifies that the particular coefficient is statistically significant at the five per cent level and * at a ten per cent level.

Asian financial crisis (AFC), Dot-com bubble (Dot-com), Sub-prime crisis (Sub-prime), European debt crisis (EU Debt)

Table 4 above depicts the influence of the five foreign markets on the JSE All share index during the four crises under observation. As one would intuitively guess, volatility transmission ought to increase over crisis periods.
This is visible from the results - there are only five statistically significant occasions of volatility spill-over from foreign markets onto the JSE All share index in periods before crises and after crises, while nine instances of 
statistically significant volatility spill-over effects are recorded during the height of the different crises.

Although these results are widely dispersed, it does seem as if volatility transmission dissipates over time. During the Asian financial crisis, for example, all of the markets but the Hang Seng displayed statistically significant volatility spill-over effects to the JSE. By the Dot-com crisis, only the CAC and the DJIA displayed statistically significant volatility spill-over effects on the JSE, and during the Sub-prime crisis only the CAC and the FTSE100. The CAC also displayed statistically significant volatility spill-over effects on the JSE during the EU Debt crisis. These volatility spill-over effects are again more prevalent after the Asian financial crisis than any other post-crisis period.

It is interesting to note that, as was the case with volatility persistence, volatility transmission was prominent from the DJIA to the JSE over the Dot-com crisis. This might be explained by the fact that during this crisis period, the originating country was hit by a financial and political crisis at the same time. Unfortunately, it is difficult because of its timing to measure the impact of the $9 / 11$ terror attacks in isolation in terms of price and volatility transmission. ${ }^{8}$

Although volatility spill-over effects seem to dissipate over time, some markets still display statistically significant volatility spillover effects to the JSE during and after the Sub-prime and EU Debt crises. In these cases, investor behaviour may be influenced not by a negative emerging market sentiment as experienced during the Asian financial crisis, but rather a general flight to more secure asset classes. This herding behaviour seems to be an appropriate assumption during the 9/11 terror attacks as well.

When investigating the relationship of specific markets compared to that of the JSE, it is clear that the volatility spill-over effects from the Hang Seng was never visible before the EU Debt crisis. This is also the first time that South Africa had strong trading relationships with Asia (mainly in the form of trade relations with China). The FTSE100 behaved more or less as expected, while the
CAC was the only index that displayed influential volatility spill-over effects on the South African market during and after the Subprime crisis. Naturally, as mentioned in the context of the Asian financial crisis investor behaviour will have been a contributing factor as investors tried to shield themselves from excessive losses. ${ }^{9}$

The CAC index seems to be the most consistent "exporter" of volatility transmission towards the JSE All share index, while the biggest volatility spill-over effect comes from the FTSE100. When comparing the magnitude of the volatility transmission from the FTSE100 index experienced during the Asian Financial crisis, with the magnitude experienced during the Sub-Prime crisis, there appears to be a decrease of more than eight times from the initial transmission. This reduction of volatility spill-over effects is also observed over time for all the other markets - besides the CAC. Although the composition of the Asian Financial crisis and the Sub-Prime crisis may not be identical, these crises share many similarities (a real estate bubble at the heart of each crisis is one example). This may indicate a positive evolution in terms of the regulation of the South African financial markets in protecting the financial system from instability originating outside the borders of South Africa. ${ }^{10}$

\section{5}

\section{Conclusion}

Given the main findings from studying the price and volatility transmission during four international financial crises, it is possible to conclude that during the manifestation of an international financial crisis, the JSE All share index mostly seems to be affected through contagion by the returns of the originating crisis country. It stands to reason that strong trade and financial linkages between South Africa and the other markets under observation, may explain investor behaviour that drives the transmission of contagion effects during a financial crisis. This conclusion is drawn since volatility transmissions during international financial crises appear to emanate directly from the originating crisis country or region. 
The results also clearly show that the South African equity market is becoming more integrated in "normal economic" conditions but that the JSE experienced reduced returns and volatility spill-over effects in later years. This is evident from the reduction in both the amount and intensity of returns and volatility spill-over effects experienced over the SubPrime and EU Debt crises. In order to ensure the future stability of the South African financial system, the South African government has proposed the establishment of a Single Financial market bill. The bill consists of a broad reform of rules and regulations in the financial sector aimed at increasing the stability of banks and insurers, as well as under-regulated products such as derivatives and hedge funds, under bill. This should ensure that the JSE continues to be shielded from contagion effects from foreign countries during crisis periods.

After the Sub-prime crisis, the regulatory scene is also livening up internationally. The most recent example of this is the Volcker rule $^{11}$ and the Dodd-Frank financial regulatory reform bill. ${ }^{12}$ In essence, from an international and South African perspective, there appears to be a shift towards greater interventionist regulatory framework, which places emphasis on restructuring of the alternative financial market sector and requiring banks to move away from complex "shadow banking systems" towards a more transparent basic banking model, which facilitates easier regulation and oversight.

Future research may endeavour to find links between South Africa's regulatory progression and the impact that international crises had on the South African financial market. Being able to prove that regulation was indeed the most important factor in the reduction of spill-over effects to the South African market will serve as motivation for financial institutions to adhere to regulation. It should also promote these institutions' willingness to put their own precautionary measures in place before rolling out new products and financial instruments.

\section{Endnotes}

1 Barclay et al. (1990) found evidence of correlations among dual listed equities on the NYSE and the TSE.

2 Hamao et al. (1990) found that volatility transmission effects between New York and London to be weaker than the transmission effect between the Japanese market and New York. Koutmos and Booth (1995) also found volatility spill-over effects between New York, London and Tokyo.

3 Lin et al. (1994) used a signal-extraction (SE) model and an aggregate shock (AS) model to study how returns volatilities of stock indices are correlated between Tokyo and New York.

4 See Ramchand and Susmel (1998) on their investigation of the relationship between time and state varying volatility and correlation between the United States and Japan, the U.K., Germany as well as Canada; and Ng (2000) who investigates the extent to which volatility within the Pacific-Basin region is influenced by a world factor, and how much is explained by a regional factor.

5 All the data was sourced from McGregor BFA, a professional provider of stock market data.

6 This study employs a similar methodology to the one used by Lin et al. (1994) and Samouilhan (2006) with regards to the use of an AS model.

7 All series were first tested for stationarity (all were non-stationary in levels) and then transformed by taking the natural logarithm differences of the weekly averages.

8 In their study of volatility transmission patterns and terrorist attacks, Chulia et al., (2009) found volatility transmission between the US and Eurozone equity markets, but noted that the 9/11 attacks occurred during a severe economic downturn.

9 In 2007 foreigners were net sellers of R5.5 billion in equities and R841 million in bonds. This sell-off by foreigners continued during 2008, with net sell-offs of R429 million in equities and R1.6 billion in bonds (JSE, 2012). Notice the initial flight from equities at the onset of the crisis, and the reversal into bonds a year later.

10 As noted earlier, South Africa's sound regulatory system can be praised for limiting the effects of the Sub-Prime crisis on the local financial system (IMF, 2010:1).

11 This legislation is aimed at protecting individuals. By increasing the transparency of financial markets, the Volcker rule places trading restrictions on financial institutions by separating the investment banking, private equity, and hedge fund functions from their consumer services business.

12 This bill was created to prevent the collapse of major financial institutions, such as Lehman Brothers at the peak of the SubPrime crisis, by increasing government oversight of trading in complex financial instruments. The reform bill also establishes government agencies to number banking practises of troubled financial institutions, in an attempt to protect unsuspecting borrowers against unfair lending and mortgage practices. 


\section{References}

ALLEN, F. \& GALE, D. 2000. Financial contagion. Journal of Political Economy, 108(1):1-33.

BAELE, L. \& INGHELBRECHT, K. 2010. Time-varying integration, interdependence and contagion. Journal of International Money and Finance, 29(5):791-818.

BARCLAY, M., LITZENBERGER, R. \& WARNER, J. 1990. Private information, trading volume and stock return variances. Review of Financial Studies, 3(2):233-252.

BOSHOFF, W.H. 2006. The transmission of foreign financial crises to South Africa: A firm-level study. Journal for Studies in Economics and Econometrics, 30(2):61-85.

CHEUNG, W., FUNG, S. \& TSAI, S. 2010. Global capital market interdependence and spill-over effect of credit risk: evidence from the 2007-2009 global financial crisis. Applied Financial Economics, 20(1):85-103. CHULIA, H., CLIMENT, F.J., SORIANO, P. \& TORO, H. 2009. Volatility transmission patterns and terrorist attacks. Quantitative Finance, 9(5):607-619.

COLLINS, D. \& ABRAHAMSON, M. 2004. African equity markets and the process of financial integration. South African Journal of Economics, 72(4):658-683.

COLLINS, D. \& BIEKPE, N. 2003. Contagion and interdependence in African stock markets. South African Journal of Economics, 71(1):181-194.

DALY, K. 2008. Financial volatility: Issues and measuring techniques. Physica A: Statistical Mechanics and its Applications, 387(11):2377-2393.

EDWARDS, S. 2000. Contagion. The World Economy, 23(7):873-900.

FORBES, K.J. 2004. The Asian flu and Russian virus: the international transmission of crises in firm-level data. Journal of International Economics, 63(1):59-92.

GATEV, E. \& STRAHAN, P.E. 2006. Banks' advantage in hedging liquidity risk: Theory and evidence from the commercial paper market. The Journal of Finance, 61(2):867-892.

GLICK, R. \& ROSE, A.K. 1999. Contagion and trade: Why are currency crises regional?

Journal of International Money and Finance, 18(4):603-617.

HAMAO, Y., MASULIS, R.W. \& NG, V. 1990. Correlations in price changes and volatility across international stock markets. The Review of Financial Studies, 3(2):281-307.

HUNG, B.W.S \& CHEUNG, Y.L. 1995. Interdependence of Asian emerging equity markets. Journal of Business Finance and Accounting, 22(2):281-288.

INTERNATIONAL MONETARY FUND. 2010. South Africa: Report on the observance of standards and codes on banking supervision, insurance supervision, and securities regulation. IMF Country report No.10/352. (Washington). Dec.

JOHANNESBURG SECURITIES EXCHANGE (JSE). 2012. Equity market statistics. Available at: http://www.jse.co.za/Markets/Equity-Market/Equity-Market-Statistics.aspx [accessed 2012-05-11].

KAMINSKY, G. \& REINHART, C. 2000. On crisis, contagion and confusion. Journal of International Economics, 51(1):145-168.

KAMINSKY, G.L., REINHART, C. \& VEGH, C.A. 2003. The unholy trinity of financial contagion. NBER Working Paper No. 10061. (Cambridge).

KANAS, A. 1998. Volatility spillovers across equity markets: European evidence. Applied Financial Economics, 8(3):245-256.

KOUTMOS, G. \& BOOTH, G.G. 1995. Asymmetric volatility transmission in international stock markets. Journal of International Money and Finance, 14(6):747-762.

LIN, W., ENGLE, R. \& ITO, T. 1994. Do bulls and bears cross borders? International transmission of stock returns and volatility. The Review of Financial Studies, 7(3):507-538.

MCGREGOR BFA DATABASE. 2013. Supplier of data. Available at: https://expert.mcgregorbfa.com/ [accessed 2012-08-30].

NG, A. 2000. Volatility spillover effects from Japan and the US to the Pacific-Basin. Journal of International Money and Finance, 19(2):207-233.

PIESSE, J. \& HEARN, B. 2005. Integration and the asymmetric transmission of volatility: A study of equity markets in sub-Saharan Africa. South African Journal of Economics, 73(1):36-53. 
PRATI, A., BARTOLINI, L. \& BERTOLA, G. 2003. The overnight interbank market: Evidence from the G-7 and the Euro zone. Journal of Banking and Finance, 27(10):2045-2083.

RAMCHAND, L. \& SUSMEL, R. 1998. Volatility and cross correlation across major stock markets. Journal of Empirical Finance, 5(4):397-416.

ROMER, C.D. 1990. The great crash and the onset of the great depression. The Quarterly Journal of Economics, 105(3):597-624, Aug.

ROSS, S.A. 1989. Information and Volatility: The no-arbitrage martingale approach to timing and resolution irrelevancy. The Journal of Finance, 1989(44):1-17.

SBRACIA, M. \& ZAGHINI, A. 2003. The role of the banking system in the international transmission of shocks. The World Economy, 26(5):727-754.

SAMOUILHAN, N.L. 2006. The relationship between international equity market behaviour and the JSE. South African Journal of Economics, 74(2):248-260.

TANIZAKI, H. \& HAMORI, S. 2009. Volatility transmission between Japan, UK and USA in daily stock returns. Empirical Economics, 36(1):27-54.

VAN RIJCKEGHEM, C. \& WEDER, B. 2001. Sources of contagion: Is it finance or trade? Journal of International Economics, 54(2):293-308.

XU, X. \& FUNG, H. 2005. Cross market linkages between U.S. and Japanese precious metals futures trading. International Financial Markets, Institutions and Money, 15(2):107-124. 